\title{
Peran Studi Kelayakan Bisnis Dalam Peningkatan UMKM (Studi Kasus UMKM di Kabupaten Kudus)
}

\author{
Oleh : \\ Karebet Gunawan, SE, MM \\ Institut Agama Islam Negeri Kudus \\ betaguna@gmail.com
}

\begin{abstract}
Kudus Regency is one of the districts in Central Java whose economic activities that are dominated by the industrial sector both in large industries such as the Djarum and Pura Barutama, and small industries. The industrial sector is the main pillar of the economy of Kudus with a contribution about 63.55 percent. The research approach used in this study is a qualitative approach, where the author does not use statistical data in collecting and identifying data. Qualitative methods are best used to develop theories that are built from data obtained through the field. Operational Management is a function or management activity that includes planning, organization, staffing, coordination, direction and supervision of the company's operations. There are three main problems faced by the company such as the problem of determining the company position, design, and other operational problems. Determination of the company position in the community aims to have the company in accordance with community needs, and can be run economically, effectively and efficiently. The similarities between theory and practice, for example, share market segmentation so that in determining what items will be sold or produced according to market needs so that the segments will be targeted or the segments to be targeted, the position of goods will also be determined. While differences in practice in determining production or sales do not use calculations such as through sales forecasts and targets to be achieved.
\end{abstract}

Keywords: Business feasibility study, market aspects, technical aspects

\section{A. PENDAHULUAN}

Pada dasarnya, keberadaan UMKM tidak lepas dari usaha pemilik usaha untuk memenuhi kebutuhan ekonomi dan meningkatkan taraf hidup. Pola fikir (mindset) pelaku usaha kecil dan usaha menengah adalah selalu ada keuntungan selama usaha masih dapat berjalan serta sangat mengandalkan insting bisnis dalam menjalankan usaha. Terdapat banyak faktor yang menentukan usaha dapat sukses atau tidak, diantaranya adalah peluang pasar, kondisi persaingan, dan trend bisnis. Oleh karena itu, secara teori tidak cukup hanya mengandalkan insting dalam mengambil keputusan di dunia bisnis. Lebih dari itu, diperlukan suatu kalkulasi yang komprehensif baik secara kualitatif maupun kuantitatif dari segala aspek yang berkaitan dengan usaha yang akan dibuat. UMKM agar dapat lebih bersaing dan memiliki prospek perkembangan yang bagus, maka sebelum mendirikan UMKM sebaiknya dilakukan studi kelayakan usaha terlebih dahulu. Hal ini berguna untuk memperhitungkan kemungkinan apakah usaha dapat bersaing dan bertahan diantara para kompetitornya sekaligus melihat kemungkinan pengembangan usaha di masa depan yang dilihat dari berbagai aspek atau sudut pandang. 
Ketika perekonomian Indonesia dihadapkan kepada krisis yag multi dimensi, industri kecil menengah (UMKM) tetap bertahan dan mampu berperan untuk melaksanakan fungsinya baik dalam memproduksi barang dan jasa di tengah kondisi usaha besar tidak mampu mempertahankan eksistensinya. Hal ini cukup beralasanmengingat sektor usaha kecil dan menengah (UMKM)memiliki prospek untuk dikembangkan, juga memiliki karakteristik yang berbeda dengan usaha besar dilihat dari skala usaha, jumlah tenaga kerja, dan kapasitas produksi sehingga memiliki ketangguhan dan ketahanan dalam menjaga kelangsungan usaha.

Studi kelayakan bisnis atau yang biasa disingkat dengan SKB adalah kegiatan terencana yang dilakukan untuk mempelajari secara lebih mendalam mengenai suatu usaha ataupun bisnis yang akan dijalankan, usaha tersebut pada akhirnya akan memberikan kesimpulan mengenai layak atau tidaknya sebuah usaha bisnis dijalankan. Studi kelayakan bisnis sangat penting karena untuk kebaikan kelangsungan kehidupan perusahaan di masa yang akan datang, dan agar tidak ada pihak-pihak yang merasa dirugikan dari terlaksananya sebuah usaha bisnis. Secara lebih lengkap, berikut ini merupakan beberapa tujuan yang ingin dicapai dari pelaksanaan sebuah Studi Kelayakan Bisnis (SKB)

Pertama, menghindari kerugian. Analisa yang dilakukan melalui studi kelayakan bisnis bertujuan untuk memperkirakan bagaimana kemungkinan untung rugi sebuah perusahaan di masa yang akan datang. Jika di dalam analisa terdapat kerugian perusahaan yang kemungkinannya akan lebih besar, maka ada baiknya pelaku usaha berpikir ulang jenis usaha yang akan dipilih. Kedua, memudahkan pelaksanaan kerja. Adanya analisa akan membantu pelaku usaha untuk merealisasikan program-program perusahaan. Pelaku usaha dapat memilih kebijakan yang dirasa menguntungkan ataupun merugikan. Ketiga, memudahkan perencanaan perusahaan. Analisa yang baik akan membantu pelaku usaha dalam merencanakan segala hal yang menyangkut dengan kegiatan perusahaan. Langkah dan program apa yang akan disusun akan menjadi lebih mudah dengan adanya studi kelayakan bisnis. Keempat, memudahkan dalam hal pengawasan. Kegiatan sebuah bisnis besar memerlukan proses pengawasan dari pihak yang berwenang seperti pemerintah. Adanya laporan analisa mengenai studi kelayakan sebuah bisnis akan menjadi panduan bagi pihak-pihak berwenang dalam hal melakukan pengawasan. Kelima, memudahkan proses pengendalian. Pengawasan dan pengendalian dalam operasi sebuah perusahaan besar perlu dilakukan secara berkesinambungan. Proses yang salah dari keduanya akan memberikan dampak buruk bagi kesehatan lingkungan maupun masalah sosial lainnya. Adanya studi kelayakan bisnis akan lebih memudahkan bagi pihak yang berwenang atau perusahaan terkait untuk melakukan pengawasan serta pengendalian.

Peranan studi kelayakan bisnis sangat besar untuk keberhasilan dan kelangsungan bisnis UMKM. Tujuan yang ingin dicapai dalam konsep studi kelayakan bisnis sebagaimana yang telah dijelaskan sebelumnya, bahwa ada banyak pihak yang berkepentingan dengan studi kelayakan bisnis sehingga jika dirumuskan secara eksplisit tujuan yang ingin dicapai dan konsep studi kelayakan bisnis sekurang-kurangnya ada empat pihak yang berkepentingan, yaitu sebagai berikut $\underline{3}$ : Pertama bagi pihak investor, studi kelayakan bisnis ditujukan untuk melakukan penilaian dan kelayakan usaha atau proyek untuk menjadi masukan yang berguna karena sudah rnengkaji berbagai aspek seperti aspek pasar, aspek teknis dan operasi, aspek organisasi dan manajemen, aspek lingkungan dan aspek finansial secara komprehensif dan detail sehingga dapat dijadikan dasar bagi investor untuk membuat keputusan investasi yang lebih objektif. Kedua bagi UMKM sebagai analisis studi kelayakan, adalah suatu alat yang berguna, yang dapat dipakai sebagai penunjang kelancaran tugas-tugas dalam melakukan penilaian suatu usaha baru, pengembangan usaha baru, pengembangan usaha atau menilai kembali usaha 
yang sudah ada. Ketiga bagi masyarakat, hasil studi kelayakan bisnis merupakan suatu peluang untuk meningkatkan kesejahteraan dan perekonomian rakyat, baik yang terlihat langsung maupun yang muncul karena adanya nilai tambah sebagai akibat dan adanya usaha tersebut.

Keempat studi kelayakan bisnis berguna bagi pemerintah. Dari sudut pandang mikro, hasil dari studi kelayakan berguna sebagai informasi pengembangan sumber daya manusia, berupa penyerapan tenaga kerja. Selain itu, adanya usaha baru atau berkembangnya usaha lama sebagai hasil dari studi kelayakan bisnis yang dilakukan oleh individu atau badan usaha, akan menambah pemasukan pemerintah, baik dan pajak pertambahan nilai maupun dan pajak penghasilan $(\mathrm{PPh})$ dan retribusi berupa biaya perijinan, biaya pendaftaran, biaya administrasi, dan lainnya yang layak diterima sesuai dengan ketentuan yang berlaku. Secara makro pemerintah studi kelayakan bisnis ini adalah untuk mempercepat pertumbuhan ekonomi daerah ataupun nasional sehingga tercapai pertumbuhan dan kenaikan income perkapita daerah. Usaha mikro kecil menengah sangat membantu negara maka mahasiswa diharapkan bisa membuat usaha maupun membantu UMK maka perlu dianalisis Peran Studi Kelayakan Bisnis Dalam Peningkatan UKM.

\section{B. KAJIAN PUSTAKA}

\section{Pengertian UMKM}

Pengertian UMKM pada kajian ini mengacu pada Undang-undang UKM Nomor 20 Tahun 2008, yaitu (http://peuyeumcipatat.blogspot.com) singkatan dari Usaha Mikro, Kecil, dan Menengah. UMKM diatur berdasarkan UU Nomor 20 tahun 2008 tentang Usaha Mikro, Kecil,dan Menengah.

a. Usaha Mikro adalah usaha produktif milik orang perorangan dan/atau badan usaha perorangan yang memenuhi kriteria Usaha Mikro sebagaimana diatur dalam Undang-Undang ini.

b. Usaha Kecil adalah usaha ekonomi produktif yang berdiri sendiri, yang dilakukan oleh orang perorangan atau badan usaha yang bukan merupakan anak perusahaan atau bukan cabang perusahaan yang dimiliki, dikuasai, atau menjadi bagian baik langsung maupun tidak langsung dari usaha menengah atau usaha besar yang memenuhi kriteria Usaha Kecil sebagaimana dimaksud dalam Undang-Undang ini.

c. Usaha Menengah adalah usaha ekonomi produktif yang berdiri sendiri, yang dilakukan oleh orang perseorangan atau badan usaha yang bukan merupakan anak perusahaan atau cabang perusahaan yang dimiliki, dikuasai, atau menjadi bagian baik langsung maupun tidak langsung dengan Usaha Kecil atau usaha besar dengan jumlah kekayaan bersih atau hasil penjualan tahunan sebagaimana diatur dalam Undang-Undang ini.

\section{Kriteria UMKM}

\begin{tabular}{|c|l|l|l|}
\hline \multirow{2}{*}{ No. } & \multicolumn{1}{|c|}{ URAIAN } & \multicolumn{2}{|c|}{ KRITERIA } \\
\cline { 3 - 4 } & & \multicolumn{1}{|c|}{ ASSET } & \multicolumn{1}{c|}{ OMZET } \\
\hline 1. & USAHA MIKRO & Maks. 50 Juta & Maks. 300 Juta \\
\hline 2. & USAHA KECIL & $>$ 50 Juta - 500 Juta & $>$ 300 Juta - 2,5 Miliar \\
\hline 3. & USAHA MENENGAH & $>$ 500 Juta -10 Miliar & $>$ 2,5 Miliar - 50 Miliar \\
\hline
\end{tabular}


Usaha Besar adalah usaha ekonomi produktif yang dilakukan oleh badan usaha dengan jumlah kekayaan bersih atau hasil penjualan tahunan lebih besar dari Usaha Menengah, yang meliputi usaha nasional milik negara atau swasta, usaha patungan, dan usaha asing yang melakukan kegiatan ekonomi di Indonesia. Asset yang ada dalam usaha mikro, usaha kecil dan usaha menengah yang diperhitungkan adalah asset diluar tanah dan bangunan jadi walaupun asset tanah dan bangunan lebih dari 50 jt tapi bisa juga masuk dalam usaha kecil.

\section{Pengertian Studi Kelayakan Bisnis}

Bisnis merupakan seluruh kegiatan yang diorganisasikan oleh orang orang yang berkecimpung di dalam bidang perniagaan (produsen, pedagang, konsumen, dan industri dimana perusahaan berada) dalam rangka memperbaiki standar serta kualitas hidup para pelaku usaha. Studi kelayakan bisnis merupakan penelaahan atau analisis tentang apakah suatu kegiatan investasi memberikan manfaat atau hasil bila dilaksanakan. Studi kelayakan bisnis merupakan penelitian terhadap rencana bisnis yang tidak hanya menganalisis layak atau tidak layak bisnis dibangun, tetapi juga saat dioperasionalkan secara rutin dalam rangka pencapaian keuntungan yang maksimal untuk waktu yang tidak ditentukan, misalnya rencana peluncuran produk baru sampai pada pengembangan. Arti dari studi kelayakan bisnis yaitu penelitian tentang layak tidaknya suatu proyek ( biasanya tentang proyek investasi ) dilaksanakan dengan berhasil. Criteria berhasil ada dua yaitu berhasil dalam arti luas dan dalam arti yang terbatas (Husnan, 2000)

\section{Aspek-aspek Studi Kelayakan Bisnis}

Dalam tahap persiapan dan analisis suatu kelayakan bisnis perlu dipertimbangkan berbagai aspek yang mungkin terlibat dan saling berkaitan satu sama lain. Secara umum aspek-aspek yang perlu diperhatikan dalam studi kelayakan bisnis meliputi aspek pasar, aspek teknis, aspek manajemen dan hukum, aspek sosial ekonomi, aspek lingkungan, dan aspek finansial. Studi kelayakan bisnis meliputi 3 aspek yaitu: Aspek pasar terdiri dari: pasar konsumen dan produsen, Aspek internal perusahaan terdiri dari: pemasaran, teknik dan teknologi, manajemen, Sumber daya manusia, dan keuangan, Aspek lingkungan terdiri dari politik, ekonomi dan sosial; lingkungan industri; yuridis (legal) dan lingkungan hidup.

\section{a. Aspek Pasar}

Sebelum mengerjakan suatu bisnis, hendaknya analisis terhadap pasar potensial yang akan dimasuki oleh produk yang akan dihasilkan oleh perusahaan dilakukan terlebih dahulu. Dengan demikian akan diketahui keberadaan pasar potensial yang dimaksud. Atau, bisnis akan mencoba menciptakan pasar potensialnya sendiri sehingga produk dapat menjadi leader. Atau, oleh karena hasil analisis menyatakan bahwa produk dan bisnis yang akan ditawarkan akan sulit diterima oleb pasar potensialnya, maka rencana bisnis akan dianggap tidak layak. Keseluruhan analisis ini hendaknya dilakukan dalam salah satu aspek SKB yaitu aspek Pasar.

\section{b. Aspek Pemasaran}

Ketiga kegiatan besar ini terkait satu sama lain dalam rangka mensukseskan studi atas aspek pemasaran. Oleh karena itu, keseluruhan analisis untuk ketiga kegiatan ini hendaknya dilakukan secara cermat, sehingga dapat diketahui apakah bisnis untuk barang/jasa yang akan digeluti adalah layak atau tidak ditinjau dan aspek pemasaran. Jika, ide bisnis ternyata dinilai tidak layak, perlu dicari apakah misalnya ada usaha-usaha yang dapat dilakukan untuk 
menjadikan ide bisnis menjadi layak. Jika memang tidak ada jalan lain, maka lebih tepat mengambil keputusan untuk mundur dan rencana bisnis tersebut.

Kepuasan konsumen adalah tingkat perasaan konsumen setelah membandingkan antara apa yang dia terima dan harapannya. Seorang pelanggan, jika merasa puas dengan nilai yang diberikan oleh produk atau jasa, sangat besar kemungkinannya menjadi pelanggan dalam waktu yang lama. Faktor-faktor yang mempengaruhi kepuasan pelanggan adalah mutu produk dan pelayanannya, kegiatan penjualan, pelayanan setelah penjualan, dan nilai-nilai penusahaan. Kegiatan penjualan terdiri atas variabel-variabel pesan (sebagai penghasil serangkaian sikap tertentu mengenai perusahaan, produk dan tingkat kepuasan yang dapat diharapkan oleh pelanggan), sikap (sebagai penilaian pelanggan atas pelayanan perusahaan), perantara (sebagai penilaian pelanggan atas perantara perusahaan seperti dealer dan grosir). Pelayanan setelah penjualan terdiri atas variabel-variabel pelayanan pendukung tertentu seperti garansi serta yang berkaitan dengan umpan balik seperti penanganan keluhan dan pengembalian uang. Selanjutnya variabelvariabel nilai perusahaan dapat dibagi atas dua macam yaltu nilai resmi yang dinyatakan oleh perusahaan sendiri dan nilal tidak resmi yang tersirat dalam segala tindakannya sehari-hari.

Kepuasan dibagi dua macam, yaitu kepuasan fungsional dan kepuasan psikologis. Kepuasan fungsional merupakan kepuasan yang diperoleh dari fungsi suatu produk yang dimanfaatkan sedangkan kepuasan psikologis merupakan kepuasan yang diperoleh dan atribut yang bersifat tidak berwujud dan produk. Selanjutnya, pelanggan pun dapat dibagi atas dua macam, yaitu pelanggan eksternal dan pelanggan internal. Pelanggan eksternal mudah diidentifikasi karena mereka ada di luar organisasi, sedangkan pelanggan internal merupakan orangorang yang melakukan proses selanjutnya dan pekerjaan orang sebelumnya.

\section{c. Aspek Teknik dan Teknologi}

Setelah dilihat dari aspek pasar maupun pemasaran, bahwa suatu rencana bisnis dianggap layak, tahap berikut yang akan dianalisis adalah mengenai aspek teknis dan teknologi. Maksudnya, apakah dan segi pembangunan proyek dan segi implementasi rutin bisnis secara teknis dapat dilaksanakan, begitu pula dengan aspek teknologi yang akan dipakai. Aspek ini dimaksudkan untuk me-review perihal manajemen operasional, terutama masalah operasionalisasinya yang terkait dengan aspek-aspek kelayakan bisnis.

\section{d. Aspek Manajemen}

Diversifikasi usaha merupakan salah satu cara untuk mengembangkan usaha perusahaan. Keputusan untuk melakukan diversifikasi adalah keputusan strategis perusahaan yang didasarkan pada analisis yang cukup mendalam. Realisasi diversifikasi usaha dimulai dan ditindaklanjuti dengan pembangunan proyek bisnis dan diimplementasikan secara rutin. Oleh karena itu, sudah tentu diperlukan manajemen yang andal untuk melaksanakannya. Proses manajemen proyek bisnis akan berakhir sampai pada bisnis selesai dibangun, selanjutnya akan digantikan oleh manajemen implementasi bisnis yang akan bekerja secara rutin sampai berakhirnya bisnis, baik oleh karena disesuaikan dengan jadwal lamanya proyek bisnis, maupun karena sebab lain, misalnya bangkrut. Bab ini, akan memaparkan aspek manajemen untuk pembangunan proyek bisnis dan 
implementasi bisnis berdasarkan pendekatan perencanaan, pengorganisasian, actuating, dan pengendalian.

\section{e. Aspek Finansial}

Tujuan menganalisis aspek keuangan dari suatu studi kelayakan bisnis adalah untuk menentukan rencana investasi melalui perhitungan biaya dan manfaat yang diharapkan, dengan membandingkan antara pengeluaran dan pendapatan, seperti ketersediaan dana, biaya modal, kemampuan bisnis untuk membayar kembali dana tersebut dalam waktu yang telah ditentukan dan menilai apakah bisnis akan dapat berkembang terus.

Studi kelayakan terhadap aspek keuangan perlu menganalisis bagaimana prakiraan aliran kas akan terjadi. Adapun beberapa indikator yang sering digunakan untuk menentukan kelayakan usaha dari aspek keuangan diantaranya:

1. Payback Period (PBP)

Payback Period adalah suatu periode yang diperlukan untuk menutup kembali pengeluaran investasi (initial cash investment) dengan menggunakan aliran kas, dengan kata lain payback period merupakan rasio antara initial cash investment dengan cash inflow nya yang hasilnya merupakan satuan waktu. Selanjutnya nilai rasio ini dibandingkan dengan maksimum payback period yang dapat diterima.

2. Internal Rate of Return (IRR)

Metode ini digunakan untuk mencari tingkat bunga yang menyamakan nilai sekarang dari arus kas yang diharapkan di masa datang, atau penerimaan kas, dengan mengeluarkan investasi awal.

3. Net Present Value (NPV)

Net Present Value atau nilai kini manfaat bersih adalah selisih antara total present value manfaat dengan total present value biaya, atau jumlah present value dari manfaat bersih tambahan selama umur bisnis. Nilai yang dihasilkan dalam perhitungan NPV adalah dalam satuan mata uang. Metode ini menghitung antara nilai sekarang dari investasi dengan nilai sekarang penerimaan-penerimaan kas bersih ( operasional maupun terminal cash flow) di masa yang akan datang (Husnan, 2000)

4. Profitability Index (PI)

Pemakaian metode Profitability Index ini caranya adalah dengan menghitung melalui perbandingan antara nilai sekarang (present value) dari rencana penerimaan-penerimaan kas bersih di masa yang akan datang dengan nilai sekarang dari investasi yang telah dilaksanakan. Metode ini menghitung perbandingan antara nilai sekarang penerimaan-penerimaan kas bersih di masa datang dengan nilai sekarang (Husnan, 2000)

5. Break Event Point (BEP)

Break Event Point adalah titik pulang pokok dimana total revenue sama dengan total cost $(\mathrm{TR}=\mathrm{TC})$, tergantung pada lama arus penerimaan sebuah bisnis dapat menutupi segala biaya operasi dan pemeliharaan beserta biaya modal lainnya. Selama suatu usaha masih di bawah BEP, maka perusahaan masih mengalami kerugian. Semakin lama mencapai titik pulang pokok, semakin besar saldo rugi karena keuntungan yang diterima masih menutupi segala biaya yang dikeluarkan. 


\section{f. Aspek Ekonomi, Sosial dan Politik}

Dalam menyusun studi kelayakan bisnis, diperlukan informasi lingkungan luar perusahaan untuk mengetahui seberapa jauh lingkungan luar tersebut berdampak bagi bisnis maupun dampak bisnis bagi lingkungan luar. Lingkungan luar meliputi aspek ekonomi, sosial dan politik.

\section{Ekonomi}

Kondisi makro ekonomi berperan signifikan pada kondisi perusahaan di Indonesia pada umumnya. Pengaruh makro ekonomi suatu daerah atau negara secara langsung atau tidak langsung adalah nyata pada rencana bisnis, apalagi bisnis dengan skala yang relatif besar. Selain menjadikan fakta makro ekonomi sebagai input dalam studi kelayakan bisnis, hendaknya perlu dikaji imbal-baliknya, yaitu bahwa bisnis yang direncanakan hendaknya bermanfaat bagi pihak lain. Aspek-aspek penilaian manfaat bisnis yang direncanakan dapat ditinjau dan beberapa sisi yang penjelasannya disajikan berikut ini .

2. Aspek sosial

Tujuan utama perusahaan adalab mencari keuntungan yang sebesar-besarnya. Namun demikian, perusahaan tidak dapat hidup sendirian. Perusahaan hidup bersama-sama dengan komponen lain dalam satu tatanan kehidupan yang pluralistis dan kompleks, walau hendaknya selalu berada dalam keseimbangan. Salah satu komponen yang dimaksud adalah lembaga sosial, sehingga dalam rangka keseimbangan tadi, hendaknya perusahaan memiliki tanggung jawab sosial.

g. Aspek Lingkungan Industri (Amirullah, 2005)

Aspek lingkungan industri lebih mengarah pada aspek persaingan di mana bisnis perusahaan berada. Akibatnya, faktor-faktor yang mempengaruhi kondisi persaingan, seperti ancaman pada perusahaan dan kekuatan yang dimiliki perusahaan termasuk kondisi persaingan itu sendiri menjadi perlu untuk dianalisis guna studi kelayakan bisnis. Terdapat enam aspek untuk melengkapi aspek lingkungan industri. Keenam aspek yang menjadi pokok bahasan tersebut adalah:

1. Ancaman masuk pendatang baru

Masuknya perusahaan sebagai pendatang baru akan menimbulkan sejumlah implikasi bagi perusahaan yang sudah ada, misalnya kapasitas menjadi bertambah, terjadinya perebutan pangsa pasar serta perebutan sumber daya produksi yang terbatas. Kondisi seperti ini menimbulkan ancaman bagi perusahaan yang telah ada. Ada beberapa faktor penghambat pendatang baru masuk ke dalam suatu industri, yang sering disebut dengan Hambatan Masuk. Faktor-faktor yang dimaksud adalah sebagai berikut:

a. Skala Ekonomi. Apabila pendatang baru berproduksi dengan skala kecil, maka mereka akan dipaksa berproduksi pada biaya per unit yang tinggi padahal perusahaan yang ada tengah berupaya pada skala produksi yang terus diperbesar dan proses produksi yang terus menerus diefisienkan sehingga harga per unit barang menjadi lebih rendah.

b. Diferensiasi Produk. Diferensiasi yang menciptakan hambatan masuk memaksa pendatang barn untuk mengeluarkan biaya dan usaha yang besar untuk merebut para pelanggan yang loyal kepada perusahaan utama. Usaha besar itu misalnya adalah dengan iklan yang gencar dan pelayanan yang 
baik. Pada tahap awal, usaha-usaha ini membutuhkan biaya yang besar dan bahkan mendatangkan kerugian. Sering kali kondisi ini berjalan cukup lama.

c. Kecukupan Modal. Jenis industri yang memerlukan modal besar merupakan hambatan yang besar bagi pemain baru, terutama pada jenis industri yang memerlukan biaya yang besar untuk riset dan pengembangan serta eksplorasi.

d. Biaya Peralihan. Hambatan masuk akan tercipta dengan adanya biaya peralihan pemasok, yaitu biaya yang harus dikeluarkan pembeli bilamana berpindah dan produk pemasok tertentu ke produk pemasok lainnya. Biaya peralihan (switching cost) ini dapat berupa biaya pelatihan kembali karyawan, biaya peralatan pelengkap yang baru, dan desain ulang produk. Pada akhirnya, biaya-biaya ini akan ditanggung oleh konsumennya. Apabila biaya peralihan yang diperlukan cukup besar, pesaing baru harus memberikan penawaran yang jauh lebih menarik, terurama soal harga.

e. Akses ke Saluran Distribusi. Jalur distribusi sangat menentukan penyebaran produk. Pernsahaan yang mempunyai jalur distribusi yang luas dan bekerja secara baik akan sangat menghambat masuknya produk baru ke dalam pasar. Pendatang baru mungkin sulit memasuki saluran yang ada dan harus mengeluarkan biaya yang besar untuk membangun saluran sendiri.

2. Persaingan Sesama Perusahaan Dalam Industri

Persaingan dalam industri sangat mempengaruhi kebijakan dan kinerja perusahaan. Dalam situasi persaingan yang oligopoli, perusahaan mempunyai kekuatan yang cukup besar untuk mempengaruhi pasar. Persaingan pasar yang sempurna biasanya akan memaksa perusahaan menjadi follower termasuk dalam hal harga produk. Ancaman Dari Produk Pengganti

Perusahaan-perusahaan yang berada dalam suatu industri bersaing pula dengan produk pengganti. Walaupun karakteristiknya berbeda, barang substitusi dapat memberikan fungsi atau jasa yang sama. Ancaman produk substitusi adalah kuat bilamana konsumen dihadapkan pada sedikitnya switching cost dan jika produk substitusi itu mempunyai harga yang lebih murah atau kualitasnya sama, bahkan lebih tinggi daripada produk-produk suatu industri lainnya.

3. Kekuatan tawar menawar pembeli (buyers)

Pembeli mampu mempengaruhi perusahaan untuk memotong harga, meningkatkan mutu dan pelayanan serta mengadu perusahaan dengan kompetitor melalui kekuatan yang mereka miliki. Beberapa kondisi yang mungkin dihadapi perusahaan antara lain adalah:

4. Kekuatan tawar menawar pemasok (Suppliers)

Pemasok dapat mempengaruhi industri lewat kemampuan mereka menaikan harga atau mengurangi kualitas produk atau servis. Pemasok akan kuat apabila beberapa kondisi berikut terpenuhi:

a. Jumlah pemasok sedikit.

b. Produk/pelayanan yang ada adalah unik dan mampu menciptakan switching cost yang besar.

c. Tidak tersedia produk substitusi. 
d. Pemasok mampu melakukan integrasi ke depan dan mengolah produk yang dihasilkan menjadi produk yang sama yang dihasilkan perusahaan.

\section{h. Aspek Yuridis}

e. Perusahaan hanya membeli dalam jumlah yang kecil dan pemasok.

Untuk mengetahui apakah suatu rencana bisnis diyakini layak dan sisi yuridis maka akan dipaparkan beberapa materi peraturan-peraturan yang berlaku berkaitan dengan bisnis agar dapat dikaji lebih dalam sesuai dengan rencana bisnis yang akan dilaksanakan.

1. Siapa Pelaksana Bisnis

Pelaksana bisnis, dibagi menjadi dua macam. Yang pertama adalah badan usahanya dan yang kedua adalah oraug-orang atau individu-individu yang terlibat sebagai decision makerr. Hal ini penting agar bisnis berjalan dalam koridor peraturan-peraturan yang berlaku.

a. Bentuk Badan Usaha

Beberapa bentuk perusahaan di Indonesia, dan segi yuridisnya, adalah seperti di bawah ini:

1) Perusahaan Perseorangan. Jenis perusahaan ini merupakan perusahaan yang diawasi dan dikelola oleh seseorang. Di satu pihak Ia memperoleh semua keuntungan perusahaan, di lain pihak juga menanggung semua risiko yang timbul dalam kegiatan perusahaan.

2) Firma. Firma adalah suatu bentuk perkumpulan usaha yang didirikan oleh beberapa orang deugan menggunakan nama bersama. Di dalam firma semua anggota mempunyai tanggung jawab sepenuhnya baik sendiri-sendiri maupun bersama-sama terhadap utang-utang perusahaan pada pihak lain. Bila terjadi kerugian maka kerugian akan ditanggung bersama, bila perlu dengan seluruh kekayaan pribadi. Jika salah satu anggota keluar dan firma, firma otomatis bubar.

3) Perseroan Komanditer (CV). Perseroan Komanditer (CV) merupakan suatu persekutuan yang didirikan oleh beberapa orang yang masingmasing menyerahkan sejumlah uang dalam jumlah yang tidak perlu sama. Sekutu dalam Perseroan Komanditer ini ada dua macam, ada yang disebut sekutu komplementer yaitu orang-orang yang bersedia untuk mengatur perusahaan dari sekutu komanditer yang mempercayakan uangnya dan bertanggung jawab terbatas kepada kekayaan yang diikutsertakan dalam perusahaan.

4) Perseroan Terbatas (PT). Badan jenis mi adalah suatu badan yang mempunyai kekayaan, hak, dan kewajiban yang terpisah dan yang mendirikan dan yang memiliki. Tanda keikutsertaan seseorang memiliki perusahaan adalah dengan memiliki saham perusahaan, makin banyak saham yang dimiliki makin besar pula andil dan kedudukannya dalam perusahaan tersebut. Jika terjadi utang, maka harta milik pribadi tidak dapat dipertanggungkan atas utang perusahaan tersebut, tetapi terbatas pada sahamnya saja.

5) Perusahaan Negara (PN). Perusahaan negara adalah perusahaan yang bergerak dalam bidang usaha yang modalnya secara keseluruhan dimiliki oleh negara, kecuali jika ada hal-hal khusus berdasarkan undang-undang. Tujuan dan pendirian perusahaan negara ini adalah 
untuk membangun ekonomi nasional menuju masyarakat yang adil dan makmur.

6) Perusahaan Pemerintah yang lain. Bentuk perusahaan pemerintah yang lain di Indonesia adalah Persero, Perusahaan Umum (Perum), PerusahaanJawatan (Perjan), dan Perusahaan Daerah (PD). Persero dan Perusahaan Daerah (PD) merupakan perusahaan yang mencari keuntungan bagi negara, sedangkan untuk Perum dan Perjan bukanlah semata- mata mencari keuntungan finansial.

7) Koperasi. Koperasi merupakan bentuk badan usaha yang bergerak di bidang ekonomi yang bertujuan untuk meningkatkan kesejahteraan anggotanya yang bersifat murni, pribadi dan tidak dapat dialihkan. Jadi koperasi merupakan suatu wadah yang penting untuk kesejahteraan anggota berdasarkan persamaan. Menurut bidang usaha, koperasi dikelompokkan menjadi Koperasi Produksi, Koperasi Konsumsi, Koperasi Simpan Pinjam, dan Koperasi Serba Usaha. Sedangkan menurut luas usahanya, koperasi dibagi atas Primer Koperasi (Primkop), ialah koperasi sebagai satuan terkecil yang meibatkan secara langsung anggotanya. Pusat Koperasi (Puskop) yang merupakan gabungan paling sedikit lima primer koperasi, sedangkan Gabungan Koperasi (Gakop) merupakan gabungan paling sedikit tiga Puskop serta Induk Koperasi (Inkud) merupakan gabungan paling sedikit tiga Gakop.

b. Identitas Pelaksana Bisnis

Ada beberapa peraturan pemerintah yang perlu diketahui berkaitan dengan identitas pelaksana bisnis, disesuaikan dengan jenis perusahaan yang dipilih. Beberapa sisi dan identitas pelaksana bisnis perlu diteliti, seperti berikut ini.

1) Kewarganegaraan. Kewarganegaraan sponsor proyek perlu diketahui, hal itu ada hubungannya dengan peraturan-peraturan yang berbeda antara warga negara dengan warga negara asing dalam kaitannya dengan pendirian suatu perusahaan.

2) Informasi bank. Ketahui apakah sponsor proyek adalah debitur pada bank lain. Jika ya, perlu diketahui apakah ada keterlibatan lain misalnya terdapat kemacetan pembayaran kredit, cek kosong, maupun jaminannya.

3) Keterlibatan pidana atau perdata. Perlu juga diketahui apakah pelaksana proyek tengah terlibat dalam suatu tindakan yang dapat menimbulkan gugatan ataupun tuntutan.

4) Hubungan keluarga. Jika terdapat hubungan suami-istri atau orangtuaanak sebagai individu-individu yang terlibat dalam rencana proyek bisnis, perlu diselidiki bagaimana mereka mengatur kebijakan hartanya. Untuk suami-istri apakah mereka nikah dengan harta campuran atau terpisah, untuk orangtua-anak bagaimana kebijakan harta warisan yang dibuat.

2. Bisnis apa yang akan dilaksanakan

Selanjutnya, perlu dikaji mengenai bisnis apa yang akan dilaksanakan, apakah bisnis ini dilarang atau tidak. Beberapa sisi yang perlu dianalisis adalah sebagai berikut : 
a. Bidang Usaha. Paling tidak bidang usaha dan proyek yang akan dibangun harus sesuai dengan anggaran dasar perusahaan atau telah sesuai dengan filosofi perusahaan.

b. Fasilitas. Apabila proyek akan mendapatkan fasilitas-fasilitas tertentu, selidiki apakah pengurusannya telah diselesaikan secara sah.

c. Gangguan Lingkungan. Proyek yang akan dibuat perlu memperhatikan lingkungan sekitar tempat proyek berada. Pencemaran lingkungan yang ditimbulkan oleh proyek akan berdampak negatif pada proyek itu sendiri, seperti pencemaran udara, air, suara, dan moral masyarakat.

d. Pengupahan. Proyek yang membutuhkan tenaga kerja dengan skill yang rendah biasanya tidak kesulitan memperolehnya dan mereka pun mau dibayar dengan rendah. Sistem pengupahan perlu memperhatikan standar upah minimum yang ditetapkan pemerintah setempat karena jika dilanggar, keresahan buruh akan berdampak negatif pada proyek.

3. Lokasi Bisnis Akan Dilaksanakan

Lokasi dimana bisnis akan dibangun tidak akan terlepas dari pengaruhpengaruh yang mungkin saja dapat merugikan perusahaan. Oleh karena itu, hendaknya lokasi bisnis dipersiapkan dengan baik. Perhatikan misalnya masalah perencanaan wilayah dan status tanah.

a. Perencanaan Wilayah. Lokasi proyek harus disesuaikan dengan rencana wilayah yang telah ditetapkan oleh pemerintah agar mudah mendapatkan izin-izin yang diperlukan. Di samping itu, juga perlu diperhatikan prakiraan situasi dan kondisi lokasi proyek dalam waktu yang akan datang. Peneliti dapat mencari informasi tentang perencanaan wilayah ini, misalnya dengan menghubungi kantor Pemda setempat yang mengurusi perencanaan wilayah di mana proyek bisnis akan berada.

b. Status Tanah. Status kepemilikan tanah proyek harus jelas, jangan sampai terjadi masalah di kemudian hari. Peneliti dapat mencari informasi tentang status tanah ini, misalnya dengan menghubungi kantor Badan Pertanahan Nasional (BPN) setempat.

4. Waktu pelaksanaan bisnis

Dalam kaitannya dengan waktu pelaksanaan bisnis, tinjauan aspek yuridis terhadap izin pelaksanaan proyek bisnis menjadi penting diteliti. Semua izin harus masih berlaku dan izin-izin yang belum dimiliki haruslah dilengkapi terlebih dahulu (minimal izin prinsip).

5. Peraturan dan perundangan

Setiap usaha yang legal sudah tentu harus mengikuti aturan-aturan yang berlaku baik dalam bentuk undang-undang maupun peraturan-peraturan lain sebagai penjabaran dan undang-undang tersebut, seperti Keputusan Menteri (Kepmen), Surat Keputusan (SK) Dirjen dan Peraturan Daerah (Perda). Dengan mengikuti aturan-aturan yang ada, maka secara yunidis formal bisnis/usaha yang akan dijalankan menjadi layak.

\section{i. Aspek Lingkungan Hidup}

Aspek lingkungan hidup perlu juga dianalis kelayakannya. Analisis lingkungan hidup yang akan dijelaskan, mengacu pada analisis AMDAL (Analisis Mengenai Dampak Lingkungan). Analisis Dampak Lingkungan sudah dikembangkan oleh beberapa negara maju sejak tahun 1970 dengan nama Environmental Impact Analysis atau Environmental Impact Assessment yang 
keduanya disingkat EIA. AMDAL diperlukan untuk melakukan suatu studi kelayakan dengan dua alasan pokok, yaitu:

1. Karena undang-undang dan peraturan pemerintah menghendaki demikian. Jawaban ini cukup efektif untuk memaksa para pemiik proyek yang kurang memperhatikan kualitas lingkungan dan hanya memikirkan keuntungan proyeknya sebesar mungkin tanpa menghiraukan dampak samping yang timbul.

2. AMDAL harus dilakukan agar kualitas lingkungan tidak rusak dengan beroperasinya proyek-proyek industri. Manusia dalam usahanya untuk memenuhi keburuhan dan meningkatkan kesejahteraan melakukan aktivitas yang makin lama makin mengubah lingkungannya. Pada awalnya perubahan lingkungan itu belum menjadi masalah, tapi setelah perubahan itu menjadi di luar ambang batas, maka manusia tidak dapat mentolerir lagi perubahan yang merugikan itu.

\section{PEMBAHASAN}

Aspek Pasar dan Pemasaran, membahas mengenai segmentasi dan target pasar, jumlah permintaan dan penawaran terhadap produk, kualitas dan spesifikasi produk, metode penetapan harga, dan promosi. Dalam penelitian ini akan didapatkan bagaimana cara memasarkan suatu barang yang ada baik barang yang dihasilkan dari hasil produk maupun cara memasarkan barang dagangan yang ada. Segmentasi pasar yang ada juga harus diketahui segmen mana yang akan dibidik dan bagaimana menyesuaikan barang yang ada dengan segmen yang akan dibidik. Target pasar juga perlu ada ketentuan yang akan dibidik pasar yang mana. Dari prakiraan penjualan, perusahaan dapat memprakirakan anggaran perusahaan, dan dari anggaran perusahaan dapat ditentukan, misalnya jumlah dan macam tenaga kerja yang dibutuhkan, kecukupan alat-alat produksi, ketersediaan bahan mentah dan daya tampung gudang. Permintaan dapat diartikan sebagai jumlah barang yang dibutuhkan konsumen yang mempunyai kemampuan untuk membeli pada berbagai tingkat harga. Permintaan yang didukung oleh kekuatan tenaga beli disebut permintaan efektif, sedangkan permintaan yang didasarkan pada kebutuhan saja disebut sebagai permintaan potensial. Hukum permintaan mengatakan bahwa bila harga suatu barang meningkat, maka kuantitas barang yang diminta akan berkurang, begitu pula sebaliknya, bila harga barang yang diminta menurun, maka kuantitas barang yang diminta akan naik. Beberapa faktor dapat mempengaruhi penawaran atau bisa juga yang mempengaruhi harga, pada bagian ini beberapa faktor yang dapat mempengaruhi penawaran atau harga dijelaskan sebagai berikut:harga Barang-barang Lain. Pada permintaan barang, barang-barang ada yang saling bersaing (jika merupakan barangbarang pengganti) dalam memenuhi kebutuhan masyarakat. Barang-barang seperti ini dapat menimbulkan pengaruh yang penting kepada penawaran suatu barang ; Biaya Faktor Produksi. Pengeluaran untuk sektor ini merupakan hal penting dalam proses produksi. Jika pengeluaran-pengeluarannya tidak efisien, tindakan ini dapat mengurangi penawaran di dalam sesuatu kegiatan ekonomi tertentu ; Tujuan Perusahaan. Jika tujuan perusahaan adalah memaksimumkan keuntungan, dapat saja perusahaan tidak berusaha menggunakan kapasitas produksinya secara maksimal, tetapi pada tingkat kapasitas yang memaksimumkan keuntungannya. Tujuan perusahaan dapat bermacam-macam dan dapat menimbulkan pengaruh yang berbeda pula terhadap penentuan tingkat produksinya.Tingkat teknologi. Tingkat teknologi mempunyai peran yang penting dalam menentukan jumlah barang yang ditawarkan. Kemajuan teknologi dapat mengurangi 
ongkos produksi, mempertinggi produktivitas dan mutu, yang cenderung mengakibatkan terjadi kenaikan penawaran.Manajemen Operasional adalah suatu fungsi atau kegiatan manajemen yang meliputi perencanaan, organisasi, staffing, koordinasi, pengarahan dan pengawasan terhadap operasi perusahaan. Operasi ini merupakan suatu kegiatan (di dalam perusahaan) untuk mengubah masukan menjadi keluaran, sehingga keluarannya akan lebih bermanfaat dan masukannya. Keluaran tersebut dapat berupa barang dan/atau jasa. Tugas manajemen operasional di perusahaan adalah untuk mendukung manajemen dalam rangka pengambilan keputusan masalah-masalah produksi/operasi. Ada tiga masalah pokok yang dihadapi perusahaan, yaitu: masalah penentuan posisi perusahaan, masalah desain dan masalah operasional.Penentuan posisi perusahaan dalam masyarakat bertujuan agar keberadaan perusahaan sesuai dengan kebutuhan masyarakat, dan dapat dijalankan secara ekonomis, efektif dan efisien. Oleh karena itu, perlu diputuskan bagaimana hendaknya posisi perusahaan ditentukan. Keputusan itu meliputi, antara lain mengenai pemilihan strategi berproduksi, penentuan produk yang akan ditawarkan ke pasar, termasuk menentukan kualitasnya.Masalah desain akan mencakup perancangan fasilitas operasi yang akan digunakan. Untuk mengatasi masalah ini, hendaknya dilakukan pengambilan keputusan di bidang rancang bangun (design). Untuk proses manufakrur yang menghasilkan barang, keputusan ini antara lain meliputi: perencanaan letak pabrik, proses operasi, teknologi yang digunakan, rencana kapasitas mesin yang akan dipakai, perencanaan bangunan, tata-letak (layout) ruangan, dan lingkungan kerja.Masalah operasional timbul biasanya pada saat proses produksi sudah berjalan. Untuk proses manufaktur yang menghasilkan barang, keputusan terhadap masalah operasional ini antara lain: rencana produksi, rencana persediaan bahan baku, penjadwalan kerja pegawai, pengawasan kualitas, dan pengawasan biaya produksi.

Manajemen Operasional adalah suatu fungsi atau kegiatan manajemen yang meliputi perencanaan, organisasi, staffing, koordinasi, pengarahan dan pengawasan terhadap operasi perusahaan. Operasi ini merupakan suatu kegiatan (di dalam perusahaan) untuk mengubah masukan menjadi keluaran, sehingga keluarannya akan lebih bermanfaat dan masukannya. Keluaran tersebut dapat berupa barang dan/atau jasa. Tugas manajemen operasional di perusahaan adalah untuk mendukung manajemen dalam rangka pengambilan keputusan masalah-masalah produksi/operasi. Ada tiga masalah pokok yang dihadapi perusahaan, yaitu: masalah penentuan posisi perusahaan, masalah desain dan masalah operasional.Penentuan posisi perusahaan dalam masyarakat bertujuan agar keberadaan perusahaan sesuai dengan kebutuhan masyarakat, dan dapat dijalankan secara ekonomis, efektif dan efisien. Oleh karena itu, perlu diputuskan bagaimana hendaknya posisi perusahaan ditentukan. Keputusan itu meliputi, antara lain mengenai pemilihan strategi berproduksi, penentuan produk yang akan ditawarkan ke pasar, termasuk menentukan kualitasnya.Masalah desain akan mencakup perancangan fasilitas operasi yang akan digunakan. Untuk mengatasi masalah ini, hendaknya dilakukan pengambilan keputusan di bidang rancang bangun (design). Untuk proses manufakrur yang menghasilkan barang, keputusan ini antara lain meliputi: perencanaan letak pabrik, proses operasi, teknologi yang digunakan, rencana kapasitas mesin yang akan dipakai, perencanaan bangunan, tata-letak (layout) ruangan, dan lingkungan kerja.Masalah operasional timbul biasanya pada saat proses produksi sudah berjalan. Untuk proses manufaktur yang menghasilkan barang, keputusan terhadap masalah operasional ini antara lain: rencana produksi, rencana persediaan bahan baku, penjadwalan kerja pegawai, pengawasan kualitas, dan pengawasan biaya produksi.Persoalan-persoalan dalam proses produksi/operasi cukup banyak dan kompleks. Namun, persoalan-persoalan itu akan dipilah-pilah, dan disesuaikan dalam rangka studi kelayakan bisnis. Untuk proses 
manufaktur, persoalan-persoalan dalam proses tersebut dikelompokkan sesuai dengan masalah manajemen operasional. Pengorganisasian untuk kedua kegiatan pokok, yaitu membangun proyek maupun mengimplementasikan bisnis secara rutin, hendaknya dikaji dan beberapa sisi, seperti: bagaimana langkah-langkah dalam pengorganisasian, bagaimana asas organisasi yang hendaknya dipilih, bagaimana struktur organisasi yang dirancang, dan bagaimana prestasi organisasi yang diinginkan. Setelah dilakukan pengkajian berdasarkan aspek-aspek ini, hendaknya diakhiri dengan suatu rekomendasi, berupa hasil studi yang menyatakan bahwa rencana pengorganisasian dapat diterima atau tidak.Sama saja dengan aspek perencanaan, pengorganisasian untuk kedua kegiatan pokok, yaitu membangun proyek maupun mengimplementasikan bisnis secara rutin, hendaknya dikaji dan beberapa sisi, seperti: bagaimana langkah-langkah dalam pengorganisasian, bagaimana asas organisasi yang hendaknya dipilih, bagaimana struktur organisasi yang dirancang, dan bagaimana prestasi organisasi yang diinginkan. Setelah dilakukan pengkajian berdasarkan aspek-aspek ini, hendaknya diakhiri dengan suatu rekomendasi, berupa hasil studi yang menyatakan bahwa rencana pengorganisasian dapat diterima atau tidak.

Aspek Teknis Produksi dan Teknologis, membahas mengenai deskripsi produk, penentuan lokasi, dan lay out fasilitas. Pada UMKM kurang memperhatikan pada aspek teknis dan teknologis terutama pada usaha yang besifat jasa tetapi pada usaha yang bersifat produksi misalnya makanan atau rokok maka teknis produksi sangat penting hal ini dilakukan pada perusahaan UMKM di Kudus salah satunya adalah jenang karomah dimana tata cara pembuatan jenang sangat terkoordinasi karena salah sedikit maka jenang rasanya akan berbeda atau bahkan bisa jadi kurang enak. Lain halnya pada industry perdagangan seperti yang dijalankan oleh kurnia yang kurang memperhatikan apda masalah teknis layout karena penjualan umumnya hanya barang yang sudah ada tidak memproduksi barang.

Aspek Manajemen dan Sumber Daya Manusia, membahas mengenai struktur organisasi, job description, sistem kompensasi, program pengembangan karyawan, serta Sistem Informasi Manajemen (SIM). Pada UMKM kurang begitu ada struktur organisasi bahkan tidak terbentuk struktur organisasi karena pada UMKM usaha dijalankan sendiri yang ada hanya karyawan karyawan pelaksana atau pada pekerja harian. Sitem kompensasi jarang diterapkan pada industry perdagangan tetapi pada industry makanan ada kompensasi terutama pada saat ada even-event tertentu. Pengembangan system informasi manajemen yang berkaitan dengan penjualan dan karyawan kurang begitu diminati bahkan ada juga yang tidak memakai sistem informasi kalau memakai biasanya yang menggunakan atau yang mempromosikan pihak pemerintah .

2. Aspek Hukum dan Legalitas, membahas mengenai badan hukum organisasi dan jenisjenis perizinan yang diperlukan.

3. Aspek Keuangan dan Ekonomi, membahas mengenai penyusunan modal kerja dan modal investasi.

Pada aspek keuangan rata-rata UMKM yang ada jarang yang melakukan pencatatan dan pembagian keuntungan yang baik misalnya ada sebagian keuntungan yang disimpan untuk motif cadangan bila ada kekurangan modal karena sebetulnya sumber modal bisa diperoleh dari keuntungan yang disimpan atau tidak dibagi. 


\section{Kesimpulan}

Persamaan yang ada antara teori dan praktek misalnya sama-sama melakukan segmentasi pasar jadi dalam menentukan barang apa yang akan dijual maupun diproduksi disesuaikan dengan kebutuhan pasar sehingga akan terbidik segmen mana yang akan dibidik atau ditentukan segmen yang akan dilayani, posisi barang juga sangat ditentukan juga. Sedangkan perbedaan dalam dalam praktek dalam menentukan produksi atau penjualan tidak memakai perhitungan seperti lewat prakiraan penjualan maupun sasaran yang akan dicapai.

1. Penentuan segmen, target, dan posisi produk pada pasarnya.

2. Kajian untuk mengetahui hal-hal utama dan konsumen potensial, seperti perihal sikap, perilaku, serta kepuasan mereka atas produk-produk sejenis.

3. Menentukan strategi, kebijakan, dan program pemasaran.

Aspek Teknis Produksi dan Teknologis, membahas mengenai deskripsi produk, penentuan lokasi, dan lay out fasilitas. Pada UMKM kurang memperhatikan pada aspek teknis dan teknologis terutama pada usaha yang besifat jasa tetapi pada usaha yang bersifat produksi misalnya makanan atau rokok maka teknis produksi sangat penting hal ini dilakukan pada perusahaan UMKM di Kudus.

Pada aspek keuangan rata-rata UMKM yang ada jarang yang melakukan pencatatan dan pembagian keuntungan yang baik misalnya ada sebagian keuntungan yang disimpan untuk motif cadangan bila ada kekurangan modal karena sebetulnya sumber modal bisa diperoleh dari keuntungan yang disimpan atau tidak dibagi.

\section{DAFTAR PUSTAKA}

Amirullah, 2005. Pengantar Bisnis" Graha Ilmu

Badan Pusat Statistik Kabupaten Kudus (2012)

Jumingan, 2011, Studi Kelayakan Bisnis, Teori dan Pembuatan Proposal Kelayakan. Jakarta : PT Bumi Aksara

Moediayanto, 2008. Studi Kelayakan Bisnis. Yogyakarta : Departemen Pendidikan Nasional Universitas Negeri Yogyakarta.

Umar, H. 2009. Studi Kelayakan Bisnis. Jakarta : PT Gramedia Pustaka Utama

Umar, H. 2009. Studi Kelayakan Bisnis. Jakarta : PT Gramedia Pustaka Utama

Suad Husnan “ Studi kelayakan Proyek” AMP YKPN, Yogyakarta, 2000

Sriyana, 2010. Strategi Pengembangan Usaha Kecil Dan Menengah (Ukm): Studi Kasus

Di Kabupaten Bantul. Jurnal Fakultas Ekonomi Universitas Islam Indonesia, Yogyakarta

Wiliandri,R. 2014. Studi Kelayakan Bisnis. Diakses tanggal Agustus 2018 